\title{
Intravenous Lidocaine for Perioperative Use
}

\author{
Marasini Bidur, Xiaodong Qiu*, Limbu Sujata \\ Department of Anesthesiology, Zhong Da Hospital Affiliated to South East University, Nanjing, China \\ Email: *qxdong@hotmail.com
}

How to cite this paper: Bidur, M., Qiu, X.D. and Sujata, L. (2019) Intravenous Lidocaine for Perioperative Use. Open Journal of Anesthesiology, 9, 57-67. https://doi.org/10.4236/ojanes.2019.94007

Received: March 12, 2019

Accepted: April 7, 2019

Published: April 10, 2019

Copyright $\odot 2019$ by author(s) and Scientific Research Publishing Inc. This work is licensed under the Creative Commons Attribution International License (CC BY 4.0).

http://creativecommons.org/licenses/by/4.0/ cc) (i) Open Access

\begin{abstract}
Introduction and Background: Lidocaine was recognised only as a local anesthetic and anti-arrhythmic drug for past decades. Nonetheless, more recently its utility in perioperative setting is being appreciated globally. This review aims to analyse its work beyond its traditional use when employed intravenously in perioperative setting and overall impact on postoperative period. Content: A total of 41 articles were selected for study while 13 of them were chosen for data presentation. Databases such as CENTRAL, MEDLINE/Pubmed, LILACS, Ovid and Scielo were used to search the articles using keywords like Intravenous lidocaine, local anesthetics, perioperative analgesia or postoperative pain. A bolus dose of $1.5 \mathrm{mg} / \mathrm{kg}$ and maintenance dose of $2-3 \mathrm{mg} / \mathrm{kg} / \mathrm{h}$ of intravenous lidocaine was used to bring out its analgesic effect and its positive impact on postoperative stage in nearly all the selected studies. Its anti-inflammatory, antinociceptive and immunomodulatory effects were also addressed. Conclusion: Perioperative implication of systemic lidocaine not only lessens pain perception but also assures early return of bowel function, lower incidence of postoperative nausea and vomiting, opioid sparing effect and shorter length of hospital stay. Thus, implementation of lidocaine as a part of perioperative approach should be seriously considered. Its role in surgeries other than abdominal needs more detailed study. In spite of current results encouraging, it may be too early to claim its similar impact in other types of surgeries.
\end{abstract}

\section{Keywords}

Intravenous Lidocaine, Local Anaesthetics, Postoperative Analgesia, Postoperative Pain

\section{Introduction}

Pain is undoubtedly the most anticipated part of postoperative experience [1]. According to World Health Organisation, more than 300 million surgeries are performed each year globally and more than three-quarters of the patients un- 
dergoing surgery suffer postoperative pain. However, it continues to remain under-managed producing undesirable surgical outcomes thereby, increasing morbidity and mortality in many cases. In fact, it has a negative impact on quality of life, functional recovery and financial liability of a patient [2]. Thus, effective management of pain should be part of perioperative approach. With this concept, many perioperative interventions and management strategies for controlling pain have emerged [3]. Among these, the use of intravenous lidocaine as perioperative analgesia is enormously growing in popularity. This could be attributed to its pharmacological properties including effective postoperative analgesia and lack of side-effects associated with traditionally used analgesics such as opiates, which will be discussed in this article [4].

Lidocaine, 2-diethylaminoaceto-2',6'-xylidide $\left(\mathrm{C}_{14} \mathrm{H}_{22} \mathrm{~N}_{2} \mathrm{O}\right)$, is an amide local anesthetic and a class $1 \mathrm{~b}$ antiarrhythmic agent. It was first synthesized in 1942, came to use in 1948, and approved by Food and Drug Administration in 1949 [5]. Previously it was used as antiarrhythmic and local anaesthetic agent but more recent studies suggest that it has significant analgesic, anti-nociceptive, immuno-modulating, and anti-inflammatory properties. Several studies document a decrease in incidence of postoperative chronic pain, nausea, vomiting, ileus, opioid consumption and duration of hospital stay with the use of this anaesthetic agent. It was also established that these effects were rather limited to abdominal surgeries [6]. Nevertheless, lately more promising results have been observed in different types of surgeries like spinal [7] or brain surgery [8].

\section{Methodology}

Active research was carried out electronically. The method adopted was to review scientific journals, peer reviewed articles, clinical trials and meta-analysis. Databases such as CENTRAL, MEDLINE/Pubmed, LILACS, Ovid and Scielo were used to search the articles using $\mathrm{MeSH}$ terms and free text like intravenous lidocaine, local anaesthetics, perioperative analgesia or post operative pain as key words. Furthermore, references listed in the retrieved articles were also checked for relevant studies. A total of 213 articles dating from 1990 to 2017 were scanned independently by two reviewers based on the above search results, howbeit, only 60 articles were selected during primary screening mainly on the basis of study design, as randomised control trial was prioritized. Rest were discarded due to various reasons like variation in the type of study, irrelevancy to the subject matter or dates, 20 of which were discarded due to duplicity and inaccessibility of full text. After thorough discussion between the two reviewers, 41 articles were finalized. Any disagreement between the two was sorted out by consulting a third reviewer. In addition, sample size, description of pharmacology of lidocaine and language used were taken into consideration while finalizing the articles. Articles those published in language other than English with no availability of translation were discarded. Bearing in mind the type of study and outcome of the study according to the determinants like post-operative pain, nausea 
and vomiting or length of hospital stay, ultimately 13 studies were employed for data presentation (Figure 1).

\section{Pharmacokinetics}

The pharmacokinetic process of lidocaine, to a large extent, depends on the total dose, route of administration and the vascularity of the site of injection. When given intravenously, distribution occurs at a rate of $0.6-4.5 \mathrm{~L} / \mathrm{kg}$, [5] primarily in well-perfused organs such as kidney, brain and heart, and then to lesser perfused organs like skin, skeletal muscles fat and peripheral organs [1]. Its absorption begins within 1 to 5 minutes after local infiltration and 5 to 15 minutes after peripheral nerve blockade. However, irrespective of its site of administration serum levels reach its peak at 20 to 30 minutes following injection while its action lasts for 10 to 20 minutes. The elimination half-life of lidocaine is 60 to 120 minutes. Around $60 \%$ to $80 \%$ of its molecules are protein bound, with approximately $70 \%$ of the binding to alpha-1 glycoprotein alone. The anaesthetic agent is metabolized mainly to active metabolites like monoethylglycinexylidide (MEGX) and glycinexylidide by cytochrome P450 in liver [5]. Furthermore, both the agent and the metabolites are cleared via renal route at a rate of $10-20 \mathrm{ml} / \mathrm{min}$ per kilogram [5] with a fast excretion phase accounting for 8 to 17 minutes and slow excretion phase for 87 to 108 minutes. Less than $10 \%$ of lidocaine remains unchanged in urine [1].

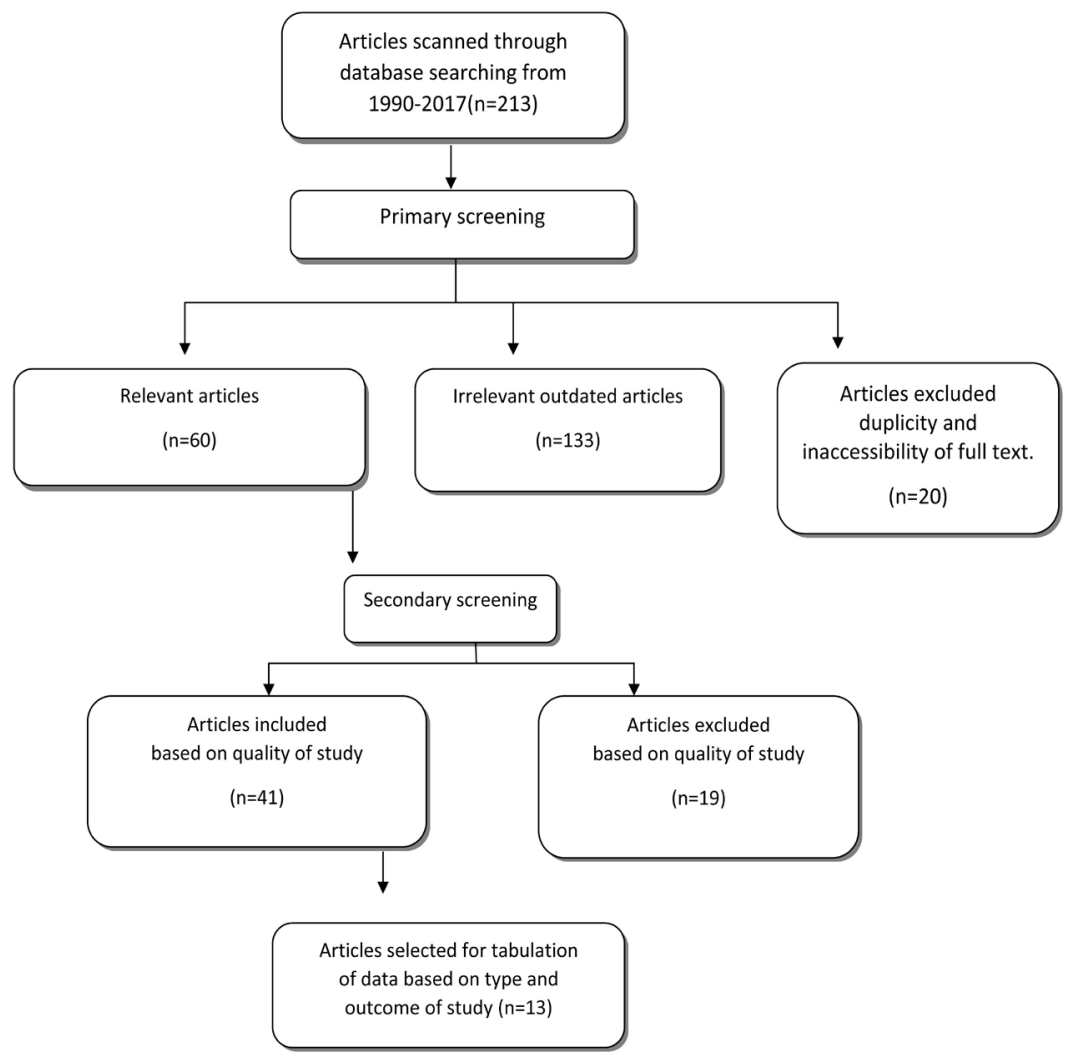

Figure 1. Flow diagram. 


\section{Pharmacodynamics}

Being an amide-based local anesthetic agent, lidocaine acts by blocking voltage-gated $\mathrm{Na}^{+}$channels (VGSC) in neuronal tissues [9]. VGSC is composed of a subunit of $260 \mathrm{kDa}$ associated with $\beta$ subunits of $33-36 \mathrm{kDa}$. $\alpha$ subunits have four homologous domains (I to IV) containing six transmembrane $\alpha$ helices (S1, S6). The $\mathrm{S} 4$ segments serve as voltage sensors and move outward to initiate activation. The S5 and S6 segments and the short membrane-associated loops between them form the pore. Fast inactivation is mediated by closure of an inactivation gate formed by intracellular loop between domains III and IV. Lidocaine blocks the pore of $\mathrm{Na}^{+}$channels by binding to a receptor site in segment $\mathrm{S} 6$ in domains III and IV [4] causing a conformational change that prevents the transient influx of sodium and, thus depolarisation. Also, it has more affinity for opened ionic channel which occurs during depolarisation. Although all potentially excitable membranes are affected, sensory fibres are blocked preferably as they are thinner, unmyelinated and more easily penetrated [10].

Apart from its classical action, its analgesic activity could be evoked through systemic use. When administered intravenously, there is an increase in the concentration of the neurotransmitter acetylcholine in cerebrospinal fluid (CSF) which stimulates the inhibitory descending pathways causing analgesia by binding to muscarinic receptors $\mathrm{M} 3$, inhibition of glycine receptors and release of endogenous opioids. When it reaches spinal cord, it reduces the post-synaptic depolarisation mediated by N-methyl-D-aspartate (NMDA) and neurokinin receptors consequently altering pain stimuli. NMDA blockade inhibits protein kinase $\mathrm{C}$, thereby minimising hyperalgesia and postoperative opioid tolerance [11].

Additionally, the agent exhibited antinociceptive effects, involving glycinergic mechanisms, in systemic usage. This was demonstrated in an experiment conducted in rat's astrocytes and frog's oocyte where the function of glycine transporter 1 (GlyT1) was studied. Lidocaine itself reduced glycine, a major inhibitory neurotransmitter, uptake only at toxic concentration whilst its metabolites MEGX, glycinexylidide and N-ethylglycine markedly reduced glycine uptake at a clinically relevant concentrate increasing extracellular glycine concentration. This rise in the level of extracellular glycine at the synaptic cleft through the blockade of GlyT1, suppress the pathologically increased conduction of excitation signals in glutamate and NMDA receptors responsible for pain stimuli, securing antinociceptive effect [12].

With regards to surgical impact on pro and anti-inflammatory systems in the body, perioperative infusion of lidocaine weakens the pro-inflammatory effects of surgery such as pain, ileus or organ failure as revealed by several studies. It acts on various steps of inflammation cascade. One of the major action recognised is blocking of priming, a process where exposure of cells to certain mediators leads to an exaggerated response like the release of cytokines and reactive oxygen species [ROS] such as superoxide anion when the cells are subsequently activated by a second mediator, of polymorphonuclear granulocyte (PMN). Moreover, PMN production of ROS much higher during trauma or 
surgery. This raised level of ROS, in turn damages the endothelium leading to vascular and organ injury. Lidocaine blocks PMN priming when cells are exposed to lidocaine at minimal concentration for prolong period of time. It has also been proposed that the same mechanism is implicated in the inhibition of specific intracellular G-protein signalling molecule (Gq). The number of studies also confirmed dose-dependent and reversible inhibition of leukocyte adhesion and migration through endothelium by inhibiting intercellular adhesion molecules, modifying the cytoskeleton, or attenuating the release of chemotactic factors. It also decreases circulating interleukin (IL) 6, phospholipase A2 levels, and production of thromboxane $\mathrm{B} 2$ all of which contributes to anti-inflammatory effect [13] [14].

\section{Adverse Effects}

Like any other local anesthetic agent, lidocaine is also not free of side-effects although extremely rare. Evidence suggests that its toxicity begins once its serum level goes beyond $5 \mathrm{mcg} / \mathrm{ml}$ while low serum concentration is enough to induce desired clinical outcomes. Convulsive seizure which is a potentially life-threatening complication associated with the use of lidocaine, occurs when its plasma level exceeds $8 \mathrm{mcg} / \mathrm{ml}$ through selective depression of depression of central inhibitory tracts. It is noteworthy that when level of carbon dioxide increases in the body, it can trigger convulsions even at lower doses. In addition, it peripherally causes vasodilation, and thusly hypotension at very large doses [15]. The intensity of toxicity depends on factors like dose and speed of injection, site of administration, blood supply of the area of injection and general status or the underlying disease condition of the patient such as hepatic or renal impairment. The adverse effects of lidocaine according to serum concentrations could be summarised as below:

- Mild (serum levels 3 - $8 \mathrm{mcg} / \mathrm{mL}$ ): Numbness and tingling in the fingers and toes, numbness and unusual sensations around and inside the mouth (perioral numbness), metallic taste, ringing in the ears, light-headedness, dizziness, visual disturbances, confusion.

- Moderate (serum levels 8 - $12 \mathrm{mcg} / \mathrm{mL}$ ): Nausea and vomiting, severe dizziness, decreased hearing, tremors, changes in blood pressure and pulse, confusion.

- Severe (serum levels > $12 \mathrm{mcg} / \mathrm{mL}$ ): Drowsiness, confusion, muscle twitching, convulsions, loss of consciousness, cardiac arrhythmias, cardiac arrest.

\section{Clinical Studies}

Various clinical trials, meta-analysis and reviews favour the perioperative use of intravenous lidocaine to facilitate better surgical outcomes. Its role as analgesic, antinociceptive, anti-inflammatory and immunomodulatory agent that makes it capable of reducing postoperative pain, lowering opioid requirement, postoperative nausea and vomiting, minimising ileus and shortening duration of hospital stay, is evident in the following clinical studies (Table 1). 
Table 1. Effects of intravenous lidocaine (IV) infusion.

\begin{tabular}{|c|c|c|c|c|c|}
\hline Reference & Type of study & $\begin{array}{l}\text { Type of } \\
\text { surgery }\end{array}$ & $\begin{array}{l}\text { Sample } \\
\text { size }\end{array}$ & Lidocaine IV infusion & Outcome \\
\hline $\begin{array}{l}\text { Farag } \\
\text { et al. [7] }\end{array}$ & RCT & $\begin{array}{c}\text { Complex } \\
\text { spine surgery }\end{array}$ & 116 & $\begin{array}{l}\text { IV lidocaine } 2 \mathrm{mg} / \mathrm{kg} / \mathrm{h} \text { with } \\
\text { maximum of } 200 \mathrm{mg} / \mathrm{h} \\
\text { during induction of anesthesia } \\
\text { and continued until discharge } \\
\text { from post anesthesia care } \\
\text { unit for maximum of } 8 \text { hours }\end{array}$ & $\begin{array}{l}\text { IV lidocaine significantly improved } \\
\text { post-operative pain after complex } \\
\text { spine surgery however, } \\
\text { post-operative nausea and vomiting } \\
\text { and the during of hospitalization } \\
\text { did not differ significantly. }\end{array}$ \\
\hline $\begin{array}{c}\text { Insler } \\
\text { et al. [16] }\end{array}$ & RCT & $\begin{array}{c}\text { CABG } \\
\text { (Coronary } \\
\text { Artery Bypass Surgery) }\end{array}$ & 100 & $\begin{array}{l}\text { IV lidocaine } 1.5 \mathrm{mg} / \mathrm{kg} \text { bolus } \\
\text { followed by } 30 \mu \mathrm{g} / \mathrm{kg} / \mathrm{min} \\
\text { during surgery } 48 \text { hours } \\
\text { post operatively }\end{array}$ & $\begin{array}{l}\text { Low dose lidocaine did not } \\
\text { significantly reduce post-operative } \\
\text { pain. Also, it had no impact on } \\
\text { time of extubation, ICU stay } \\
\text { or hospital length of stay. }\end{array}$ \\
\hline $\begin{array}{c}\text { Kang } \\
\text { et al. [17] }\end{array}$ & RCT & $\begin{array}{c}\text { Subtotal } \\
\text { gastrectomy }\end{array}$ & 48 & $\begin{array}{l}\text { IV lidocaine } 1.5 \mathrm{mg} / \mathrm{kg} \text { bolus } \\
20 \text { minutes before incision } \\
\text { followed by a continuous } \\
\text { infusion of } 1.5 \mathrm{mg} / \mathrm{kg} / \mathrm{h} \\
\text { until the end of surgery }\end{array}$ & $\begin{array}{l}\text { Intraoperative lidocaine decreased } \\
\text { opioid consumption and length } \\
\text { of hospital stay after gastrectomy. } \\
\text { No differences were noted } \\
\text { between the groups in pain } \\
\text { intensity or duration of ileus. }\end{array}$ \\
\hline $\begin{array}{l}\text { Kyoung-Tae } \\
\text { et al. }[18]\end{array}$ & RCT & $\begin{array}{c}\text { Lumbar } \\
\text { microdiscectomy }\end{array}$ & 51 & $\begin{array}{l}\text { IV lidocaine } 1.5 \mathrm{mg} / \mathrm{kg} \\
\text { bolus followed by a } \\
2 \mathrm{mg} / \mathrm{kg} / \mathrm{h} \text { infusion until } \\
\text { the end of surgery }\end{array}$ & $\begin{array}{l}\text { Lidocaine decreased pain } \\
\text { perception and hence, also the } \\
\text { consumption of opioid and the } \\
\text { severity of postoperative pain } \\
\text { that further contributed to } \\
\text { shortening of hospital stay. }\end{array}$ \\
\hline Kim et al. [19] & RCT & $\begin{array}{l}\text { Laparoscopic } \\
\text { appendectomy }\end{array}$ & 68 & $\begin{array}{l}\text { IV lidocaine } 1.5 \mathrm{mg} / \mathrm{kg} \text { bolus } \\
\text { followed by a continuous } \\
\text { infusion of } 2 \mathrm{mg} / \mathrm{kg} / \mathrm{h} \\
\text { throughout surgery }\end{array}$ & $\begin{array}{l}\text { Lidocaine reduces pain and } \\
\text { fentanyl consumption. The } \\
\text { shoulder tip pain and } \\
\text { post-operative nausea and } \\
\text { vomiting were also reduced. }\end{array}$ \\
\hline $\begin{array}{l}\text { Lauwick } \\
\text { et al. [20] }\end{array}$ & RCT & $\begin{array}{l}\text { Laparoscopic } \\
\text { prostatectomy }\end{array}$ & 40 & $\begin{array}{l}\text { IV lidocaine } 2 \mathrm{mg} / \mathrm{kg} / \mathrm{h} \text { during } \\
\text { surgery, } 1 \mathrm{mg} / \mathrm{kg} / \mathrm{min} \text { for the } \\
\text { first } 24 \mathrm{hrs} \text { after surgery }\end{array}$ & $\begin{array}{l}\text { Lidocaine infusion attenuated } \\
\text { the deterioration in functional } \\
\text { walking capacity and hand } \\
\text { an opioid sparing effect. }\end{array}$ \\
\hline Martin et al. [21] & RCT & $\begin{array}{l}\text { Total Hip } \\
\text { arthroplasty }\end{array}$ & 60 & $\begin{array}{l}\text { IV lidocaine } 1.5 \mathrm{mg} / \mathrm{kg} 30 \mathrm{~min} \\
\text { before surgical incision } \\
\text { followed by continuous } \\
\text { infusion of } 1.5 \mathrm{mg} / \mathrm{kg} / \mathrm{h} \text {. } \\
\text { The infusion ended } 60 \mathrm{~min} \\
\text { after skin closure }\end{array}$ & $\begin{array}{l}\text { The study didn't show any benefit } \\
\text { of perioperative administration } \\
\text { of low dose IV lidocaine in terms } \\
\text { of post-operative analgesia and } \\
\text { functional recovery after total } \\
\text { hip arthroplasty. }\end{array}$ \\
\hline $\begin{array}{l}\text { Oliveira } \\
\text { et al. [22] }\end{array}$ & RCT & $\begin{array}{c}\text { Laparoscopic } \\
\text { bariatric surgery }\end{array}$ & 50 & $\begin{array}{l}\text { IV lidocaine } 1.5 \mathrm{mg} / \mathrm{kg} \\
\text { bolus }+2 \mathrm{mg} / \mathrm{kg} / \mathrm{h} \text { till the } \\
\text { end of surgical procedure }\end{array}$ & $\begin{array}{l}\text { Systemic lidocaine reduced } \\
\text { opioids (morphine) consumption } \\
\text { and thereby, improving the } \\
\text { quality of post-operative recovery. }\end{array}$ \\
\hline Peng et al. [8] & RCT & $\begin{array}{l}\text { Supratentorial } \\
\text { tumor surgery }\end{array}$ & 94 & $\begin{array}{l}\text { IV lidocaine } 1.5 \mathrm{mg} / \mathrm{kg} \text { bolus } \\
\text { followed by continuous } \\
\text { infusion of } 2 \mathrm{mg} / \mathrm{kg} / \mathrm{h} \\
\text { until the end of surgery }\end{array}$ & $\begin{array}{l}\text { Systemic lidocaine profoundly } \\
\text { reduced the proportion of } \\
\text { patients with acute } \\
\text { pain after surgery. }\end{array}$ \\
\hline $\begin{array}{l}\text { Striebel } \\
\text { et al. [23] }\end{array}$ & RCT & $\begin{array}{c}\text { Elective } \\
\text { tonsillectomy (1992) }\end{array}$ & 40 & $\begin{array}{l}\text { IV lidocaine } 1.5 \mathrm{mg} / \mathrm{kg} 30 \mathrm{~min} \\
\text { before the surgery followed by } \\
2 \mathrm{mg} / \mathrm{kg} / \mathrm{h} \text { over } 6 \mathrm{hr} \text { and } \\
0.5 \mathrm{mg} / \mathrm{kg} / \mathrm{h} \text { for another } 18 \mathrm{~h}\end{array}$ & $\begin{array}{l}\text { Intravenous lidocaine did not } \\
\text { significantly reduce } \\
\text { postoperative pain after } \\
\text { tonsillectomy in the dosage used. }\end{array}$ \\
\hline
\end{tabular}




\begin{tabular}{|c|c|c|c|c|c|}
\hline $\begin{array}{l}\text { Vigneault } \\
\text { et al. [24] }\end{array}$ & $\begin{array}{l}\text { Meta-analysis } \\
\text { of } 29 \text { papers }\end{array}$ & $\begin{array}{c}7 \text { cardiac, } \\
3 \text { gynecology, } \\
1 \text { thoracic, } \\
2 \text { urology, } \\
1 \text { otorhinolaryngology, } \\
14 \text { abdominal surgery, } \\
1 \text { orthopedic surgery }\end{array}$ & 1754 & $\begin{array}{l}\text { IV lidocaine bolus prior } \\
\text { to infusion } \\
\text { (infusion rate } \leq 3 \mathrm{mg} / \mathrm{kg} / \mathrm{h} \text { ) }\end{array}$ & $\begin{array}{l}\text { IV Lidocaine infusion reduced } \\
\text { post-operative pain during rest } \\
\text { and during movement. It also } \\
\text { reduced opioid requirement, } \\
\text { nausea, vomiting, time to } \\
\text { first flatus, time to first feces and } \\
\text { length of hospital stay abdominal } \\
\text { surgery was strongly associated } \\
\text { with these outcomes. }\end{array}$ \\
\hline $\begin{array}{l}\text { Wuethrich } \\
\text { et al. [25] }\end{array}$ & RCT & $\begin{array}{l}\text { Laparoscopic } \\
\text { renal surgery }\end{array}$ & 64 & $\begin{array}{l}\text { IV lidocaine } 1.5 \mathrm{mg} / \mathrm{kg} / \mathrm{hr} \\
\text { bolus during induction } \\
\text { followed by intraoperative } \\
\text { infusion of } 2 \text { and } 1.3 \mathrm{mg} / \mathrm{kg} / \mathrm{h} \\
\text { for } 24 \text { h post operatively }\end{array}$ & $\begin{array}{l}\text { Lidocaine did not influence the } \\
\text { length of the hospital stay readiness } \\
\text { for discharge opioid consumption, } \\
\text { return of bowel function or } \\
\text { inflammatory and stress responses } \\
\text { after laparoscopic renal surgery. }\end{array}$ \\
\hline $\begin{array}{l}\text { Wongyinsinn } \\
\text { et al. [26] }\end{array}$ & RCT & $\begin{array}{c}\text { Laparoscopic } \\
\text { colorectal surgery }\end{array}$ & 60 & $\begin{array}{l}\text { IV lidocaine } 1 \mathrm{mg} / \mathrm{kg} / \mathrm{h}+\mathrm{PCA} \\
\text { (patient controlled analgesia) } \\
\text { morphine for the first } \\
48 \mathrm{~h} \text { after surgery }\end{array}$ & $\begin{array}{l}\text { Both IV lidocaine and thoracic } \\
\text { epidural analgesia (TEA) had } \\
\text { similar impact on restoration of } \\
\text { bowel function; however, TEA } \\
\text { provided better analgesia in } \\
\text { patients undergoing rectal surgery. } \\
\text { Time out of bed dietary intake } \\
\text { and hospital stay were similar. }\end{array}$ \\
\hline
\end{tabular}

Farag and colleagues conducted a trial in 116 patients undergoing complex spine surgery by randomly infusing lidocaine at $2 \mathrm{mg} / \mathrm{kg} / \mathrm{h}$ for induction (maximum of $200 \mathrm{mg} / \mathrm{h}$ ) which was continued for maximum of 8 hours postoperatively, to some and placebo to others. The group that received lidocaine reported substantial improvement in postoperative pain as compared to the placebo group. Postoperative nausea and vomiting and the duration of hospital stay did not differ significantly [7].

Insler and his associates carried out a study of in 100 subjects who were undergoing coronary artery bypass grafting (CABG) for the first time. The subjects were given intravenous lidocaine $1.5 \mathrm{mg} / \mathrm{kg} / \mathrm{min}$ during surgery and 48 hours postoperatively. Low dose lidocaine had no impact on postoperative pain. Also, it had no influence on time of extubation, Intensive Care Unit (ICU) stay or length of hospital stay [16]. Similarly, studies conducted by Martin [21], Striebel [23], as well as Wuethrich [25] and associates with similar dose of lidocaine but different type of surgeries, did not show any considerable benefits of lidocaine over placebo solution.

Kang and colleagues evaluated 48 patients submitted to gastrectomy under general anesthesia with intravenous lidocaine in bolus dose of $1.5 \mathrm{mg} / \mathrm{kg}$ at induction and same dose in continuous infusion until the end of surgery. This technique significantly diminished the opioid postoperative consumption and time of hospital stay, although this study didn't show any improvement of pain levels and return of bowel function [17].

Fifty-one patients subjected for lumbar microdiscectomy were studied by kyoung-Tae and colleagues to evaluate the analgesic effect of lidocaine infusion 
on postoperative pain. Preoperatively and throughout the surgery, one group received lidocaine infusion $(1.5 \mathrm{mg} / \mathrm{kg}$ bolus followed by $2 \mathrm{mg} / \mathrm{kg} / \mathrm{h}$ infusion until the end of surgical procedure) and the other group received normal saline infusion as placebo. Intraoperative intravenous lidocaine lessened pain perception during surgery subsequently decreasing opioid requirement and duration of hospital stay [18]. In similar fashion with similar dosage, Peng with his colleagues analysed 94 subjects enrolled for supratentorial craniotomy. Intravenous lidocaine greatly reduced acute pain after surgery [8].

Again with the same induction and maintenance dose of lidocaine, a randomised control trial was carried out in 68 patients subjected to laparoscopic appendectomy by Kim and collaborators. However, this time the samples were divided in three groups; 1) Group IP (the intravenous group) receiving intraperitoneal instillation of lidocaine and intravenous normal saline injection 2) Group IV (the intravenous group) receiving intravenous lidocaine injection and intraperitoneal instillation of normal saline 3) Group C (the placebo controlled group) receiving normal saline both intravenously and intraperitoneally. Intravenous lidocaine was found as effective as peritoneal instillation for decreasing pain and fentanyl consumption [19].

Lauwick and associates randomised forty patients undergoing laparoscopic prostatectomy to receive an intravenous infusion of either lidocaine $2 \mathrm{mg} / \mathrm{kg} / \mathrm{hour}$ during surgery and $1 \mathrm{mg} / \mathrm{kg} / \mathrm{min}$ for the first postoperative period or an equivalent volume of normal saline to assess the postoperative functional walking capacity, as a measure of surgical recovery. Lidocaine attenuated functional walking capacity and had opioid-sparing effect [20]. Clinical trial performed by Dr Oliveria and teammates in fifty patients being admitted for laparoscopic bariatric surgery also established positive results [22].

Vigneault and collaborators did a meta-analysis of 29 RCT of different types of surgeries. A bolus dose prior to infusion was given in all the trials $(\leq 3$ $\mathrm{mg} / \mathrm{kg} / \mathrm{h}$ ). It not only reduced postoperative pain but also decreased opioid consumption, nausea, vomiting, time to first flatus, time to first defecation, and length of hospital stay. These effects were more pronounced in abdominal surgeries [24].

Wongyingsinn examined 60 patient scheduled for laparoscopic colorectal surgery to test the efficiency of systemic lidocaine $1.5 \mathrm{mg} / \mathrm{kg}$ (maximum $100 \mathrm{mg}$ ) for induction and $2 \mathrm{mg} / \mathrm{kg} / \mathrm{h}$ for maintenance in comparison to thoracic epidural analgesia in terms of restoration of bowel function in postoperative period. The impact of intravenous lidocaine on the return of bowel function was similar to thoracic epidural analgesia when an enhanced recovery program was implemented [26].

To sum up, Therapeutic level of lidocaine was achieved with bolus dose of 1.5 $\mathrm{mg} / \mathrm{kg}$ and maintenance dose of 2 or $\leq 3 \mathrm{mg} / \mathrm{kg} / \mathrm{h}$ in almost all the clinical trials. Contrary to previous belief that advantages of its perioperative use is only evident in abdominal surgeries, trials conducted by Farag, kyoung-Tae and Peng provided promising results in other surgeries. Furthermore, while assessment 
done by Wongyingsinn and Kim gives hope of its future use as an alternative in cases where intraperitoneal or thoracic epidural routes are contraindicated [7] [8] [18] [19] [26] (Table 1).

\section{Conclusion}

Lidocaine is safe and has obvious advantages in perioperative use. Whether these merits are only associated with abdominal surgeries is still a subject that demands more exploration and vigorous research. However, the outcomes yielded by more recent studies are not disheartening. Moreover, its clinical implication as an alternative to thoracic epidural analgesia or anti-inflammatory agent could be another field of future interest. It would be safe to assume that this local anesthetic agent can be used at a low dose without fear of toxicity as adverse reactions are very rare and commence only at and above a plasma level of more than $5 \mathrm{mcg} / \mathrm{ml}$. Finally, it is also convenient and cost-effective which provide a basis for its use in a wide range.

\section{Acknowledgements}

We would like to thank the faculty members of Department of Anesthesia, Zhongda Hospital affiliated to Southeast University for their coordination. We would like to thank Dr Rishma Limbu for her critical review of the manuscript and her guidance.

\section{Funding}

No funding.

\section{Conflicts of Interest}

The authors declare that they have no conflicts of interest.

\section{References}

[1] Couceiro, T.C.D.M., Lima, L.C., Couceiro, L. and Valença, M.M. (2014) Intravenous Lidocaine to Treat Postoperative Pain. Revista Dor, 15, 55-60. https://doi.org/10.5935/1806-0013.20140013

[2] Apfelbaum, J.L., Chen, C., Mehta, S. and Gan, T. (2003) Postoperative Pain Experience: Results from a National Survey Suggest Postoperative Pain Continues to $\mathrm{Be}$ Undermanaged. Anesthesia \& Analgesia, 97, 534-540. https://doi.org/10.1213/01.ANE.0000068822.10113.9E

[3] Chou, R., et al. (2016) Management of Postoperative Pain: A Clinical Practice Guideline from the American Pain Society, the American Society of Regional Anesthesia and Pain Medicine, and the American Society of Anesthesiologists' Committee on Regional Anesthesia, Executive Committee, and Administrative Council. The Journal of Pain, 17, 131-157. https://doi.org/10.1016/j.jpain.2015.12.008

[4] Yardeni, I.Z., et al. (2009) The Effect of Perioperative Intravenous Lidocaine on Postoperative Pain and Immune Function. Anesthesia \& Analgesia, 109, 1464-1469. https://doi.org/10.1213/ANE.0b013e3181bab1bd 
[5] Weinberg, L., Peake, B., Tan, C. and Nikfarjam, M. (2015) Pharmacokinetics and Pharmacodynamics of Lignocaine: A Review. World Journal of Anesthesiology, 4, 17-29. https://doi.org/10.5313/wja.v4.i2.17

[6] Minami, K. and Uezono, Y. (2013) The Recent Progress in Research on Effects of Anesthetics and Analgesics on G Protein-Coupled Receptors. Journal of Anesthesia, 27, 284-292. https://doi.org/10.1007/s00540-012-1507-2

[7] Farag, E., et al. (2013) Effect of Perioperative Intravenous Lidocaine Administration on Pain, Opioid Consumption, and Quality of Life After Complex Spine Surgery. Anesthesiology, 119, 932-940. https://doi.org/10.1097/ALN.0b013e318297d4a5

[8] Peng, Y., Zhang, W., Kass, I. and Han, R. (2016) Lidocaine Reduces Acute Postoperative Pain after Supratentorial Tumor Surgery in the PACU: A Secondary Finding from a Randomized, Controlled Trial. Journal of Neurosurgical Anesthesiology, 28, 309-315. https://doi.org/10.1097/ANA.0000000000000230

[9] Scholz, A. (2002) Mechanisms of (Local) Anaesthetics on Voltage-Gated Sodium and Other Ion Channels. British Journal of Anaesthesia, 89, 52-61. https://doi.org/10.1093/bja/aef163

[10] White, P.F. (2002) The Role of Non-Opioid Analgesic Techniques in the Management of Pain After Ambulatory Surgery. Anesthesia \& Analgesia, 94, 577-585. https://doi.org/10.1097/00000539-200203000-00019

[11] Lauretti, G.R. (2008) Mechanisms of Analgesia of Intravenous Lidocaine. Revista Brasileira de Anestesiologia, 58, 280-286. https://doi.org/10.1590/S0034-70942008000300011

[12] Werdehausen, R., et al. (2012) Lidocaine Metabolites Inhibit Glycine Transporter 1A Novel Mechanism for the Analgesic Action of Systemic Lidocaine? Anesthesiology, 116, 147-158. https://doi.org/10.1097/ALN.0b013e31823cf233

[13] Cassuto, J., Sinclair, R. and Bonderovic, M. (2006) Anti-Inflammatory Properties of Local Anesthetics and Their Present and Potential Clinical Implications. Acta Anaesthesiologica Scandinavica, 50, 265-282. https://doi.org/10.1111/j.1399-6576.2006.00936.x

[14] Dunn, L.K. and Durieux, M.E. (2017) Perioperative Use of Intravenous Lidocaine. Anesthesiology, 126, 729-737. https://doi.org/10.1097/ALN.0000000000001527

[15] Becker, D.E. and Reed, K.L. (2006) Essentials of Local Anesthetic Pharmacology. Anesthesia Progress, 53, 98-109. https://doi.org/10.2344/0003-3006(2006)53[98:EOLAP]2.0.CO;2

[16] Insler, S.R., O'Connor, M., Samonte, A.F. and Bazaral, M.G. (1995) Lidocaine and the Inhibition of Postoperative Pain in Coronary Artery Bypass Patients. Journal of Cardiothoracic and Vascular Anesthesia, 9, 541-546. https://doi.org/10.1016/S1053-0770(05)80138-7

[17] Kang, J.G., et al. (2012) Intraoperative Intravenous Lidocaine Reduces Hospital Length of Stay Following Open Gastrectomy for Stomach Cancer in Men. Journal of Clinical Anesthesia, 24, 465-470. https://doi.org/10.1016/j.jclinane.2012.02.006

[18] Kim, K.-T., et al. (2014) Intraoperative Systemic Infusion of Lidocaine Reduces Postoperative Pain after Lumbar Surgery: A Double-Blinded, Randomized, Placebo-Controlled Clinical Trial. The Spine Journal, 14, 1559-1566. https://doi.org/10.1016/j.spinee.2013.09.031

[19] Kim, T.H., et al. (2011) Intraperitoneal and Intravenous Lidocaine for Effective Pain Relief after Laparoscopic Appendectomy: A Prospective, Randomized, Double-Blind, Placebo-Controlled Study. Surgical Endoscopy, 25, 3183-3190. https://doi.org/10.1007/s00464-011-1684-3 
[20] Lauwick, S., Kim, D.J., Mistraletti, G. and Carli, F. (2009) Functional Walking Capacity as an Outcome Measure of Laparoscopic Prostatectomy: The Effect of Lidocaine Infusion. British Journal of Anaesthesia, 103, 213-219. https://doi.org/10.1093/bja/aep103

[21] Martin, F., et al. (2008) Lack of Impact of Intravenous Lidocaine on Analgesia, Functional Recovery, and Nociceptive Pain Threshold after Total Hip Arthroplasty. Anesthesiology, 109, 118-123. https://doi.org/10.1097/ALN.0b013e31817b5a9b

[22] De Oliveira, G.S., et al. (2014) Systemic Lidocaine to Improve Quality of Recovery after Laparoscopic Bariatric Surgery: A Randomized Double-Blinded Placebo-Controlled Trial. Obesity Surgery, 24, 212-218. https://doi.org/10.1007/s11695-013-1077-x

[23] Striebel, H. and Klettke, U. (1992) Ist eine intravenöse Lidocaininfusion zur Therapie postoperativer Schmerzen geeignet? Der Schmerz, 6, 245-250.

https://doi.org/10.1007/BF02527813

[24] Vigneault, L., et al. (2011) Perioperative Intravenous Lidocaine Infusion for Postoperative Pain Control: A Meta-Analysis of Randomized Controlled Trials. Canadian Journal of Anesthesia, 58, 22-37. https://doi.org/10.1007/s12630-010-9407-0

[25] Wuethrich, P.Y., Romero, J. and Burkhard, F. and Curatolo, M. (2012) No Benefit from Perioperative Intravenous Lidocaine in Laparoscopic Renal Surgery: A Randomised, Placebo-Controlled Study. European Journal of Anaesthesiology, 29, 537-543. https://doi.org/10.1097/EJA.0b013e328356bad6

[26] Wongyingsinn, M., et al. (2011) Intravenous Lidocaine versus Thoracic Epidural Analgesia: A Randomized Controlled Trial in Patients Undergoing Laparoscopic Colorectal Surgery Using an Enhanced Recovery Program. Regional Anesthesia and Pain Medicine, 36, 241-248. https://doi.org/10.1097/AAP.0b013e31820d4362 